\title{
THE EFFECT OF HALAL AWARENESS, HALAL CERTIFICATION AND HALAL MARKETING TOWARD HALAL PURCHASE INTENTION OF FAST FOOD AMONG MUSLIM MILLENIALS GENERATION
}

\author{
Malik Rahmi Fitria*, Hermawan Aji, Asnawi Yudha Heryawan \\ School of Business, Bogor Agricultural University, Indonesia \\ *E-mail: rahmimalik92@gmail.com
}

\begin{abstract}
The purpose of this research is to analyze the effect of halal awareness, halal certification and halal marketing on purchase intention. Muslim millennial characteristics in this research are gender, age, occupation, income, status and domicile. The quantitative approach is carried out by online survey methods to respondents. The data were collected from October to April 2019 and respondents were selected by accidental sampling, data processing technique used in this research were SEM (Structural Equation Modelling) with Lisrel 8.3 software and descriptive analysis with SPSS 22. The results of this research indicate that halal awareness, halal certification and halal marketing have a significant influence on purchase halal purchase intention. It is characterized by positive score obtained in all the variables.
\end{abstract}

\section{KEY WORDS}

Halal awareness, halal certification, halal marketing, halal purchase intention.

Agriculture and Agri-Food Canada (2016) stated that Indonesia is one of the largest food industry markets in Asean. One of the industries that drive the development of the food industry in Indonesia is the fast food industry. Fast food is food which was served quickly, easily obtained, it feels good and using fresh ingredients nutritious, which usually have been through the first stage cooking process so that the presentation is much easier and faster (Sharkey JR et al, 2011; Rania 2017). Fast food types as stated by Alam (2013) is food from western fast food (burgers, sandwiches, fried chicken, pizza, donuts) and fast food from Japan (bento, sushi). Amelia (2018) added the fast food of Indonesia such as nasi Padang, soup, chicken porridge, nasi warteg (rice food stall).

A survey conducted by JakPat in 2016 showed that the age range of 20-39 years known to the highest number of fast food purchases. The age range of 19-38 (year of birth from 1981 to 2000) is Millennials generation or Generation Y (Ali and Purwandi 2016). One of the millennial behavior is "I want it fast, I want it now" even to the selection of food, the millennial prefer fast food. (Barton et al 2012).

When eating fast food, some consumers have their own perspective on what they consume. For examples Muslim consumers want to be sure of what foods they eat is halal, it also applies to Muslim consumer's millennial. Food that allowed in Islam is the good food or usually called halalan thayyiba means substances, does not contain carrion, blood, pork or alcohol and both of how to get it. Cloud research results et al (2015) presents religiosity set the standards of behavior of someone who directly impact on the food preferences.

In choosing halal food, Muslim millennial more likely to choose a product or service that has been certified halal. Tri (2019) states that the certification of halal for Muslims millennial merely to ensure that the product or service offered has passed the test of the Indonesian Council of Ulama (MUI), so there is no intention to know more about the product. In fact, there are some manufacturers who do not have adequate knowledge about halal food and claim their products are halal. Therefore, they display the halal logo without halal certification from MUI, where an action can be categorized as public deception (Rashid, 2010). This resulted in Muslim consumers are likely to have awareness of the food they consume. Unfortunately, the millennial Muslims tend not to find out about what they consume halal because of their lifestyle. 
Temporal (2011) reveals that the Muslims constitute a quarter of the population in the world, but it turns out the Muslim market is not homogeneous, many variables that influence consumer purchase decisions. Beyond of halal and halal certification awareness of a Muslim doing purchase intention is based marketing strategy offered out by fast food restaurants. Today's consumers are increasingly sensitive to price and quality so they tend to choose good quality products. This is the appeal of a fast food restaurant how they care for their customers especially if their customers are Muslim majority.

\section{LITERATURE REVIEW}

Purchasing intention is the behavior that appears in response to an object that shows the interest of consumers to make purchases or also a repeat purchase interest (Assael, 2004). Farouk and Fathima (2017) found consumer purchase intention in products such as food are influenced by habit what they do. If they are Muslims, they will have an interest in buying the products accordance with sharia and Islamic rules. Islam has set what is lawful and unlawful food to be consumed by Muslims.

Awareness in the context of halal food is a condition in which the consumer has a special interest based on experience and the information they know about allowed food in Islam, as a religion that believed someone would affect to the purchase intention. (Ambali, 2014; and Mathras, 2016).

Shafie (2006) claimed that halal certification is used by manufacturers to inform and reassure consumers that their products are halal and sharia-compliant. To represent the credibility of consumer products are safe for consumption by Muslims usually labelled the halal logo on their products (Wibowo \& Ahmad, 2016).

The definition of halal marketing is conceptually the same with marketing in general, the differences is in halal marketing where it should be fixed to the rules and guidelines set by the Shari'a (Salehudin and Mukhlis 2012). Nurhasanah (2018) highlights four tools of the important marketing mix to be considered in satisfying the customer and company goals as a way to evaluate how they respond to their customers in accordance with the manufacturer's marketing strategy. Islamic marketing mix consists of product, price, promotion and logistics (Alserhan 2011). But, only three variables of marketing mix that being used in this study namely: product, price and promotion.

Ali and Purwandi (2016) states millennial consumers who born in the range of 1981 2000 , estimated to be aged in the range 19-38 years now. One characteristic of Muslim generations millennial is they believe religion and modernity can go hand in hand, but did not see any cons in both of them (Janmohamed 2017). For example, the development of the food, Islamic people are required to always consume halal foods. Some Muslims millennial judge halal food if the food is labelled by halal logo. But most other millennial Muslims want a guarantee that not only the inclusion of the halal logo, but also more thoroughly covers certification and official halal information (Janmohamed, 2017).

\section{METHODS OF RESEARCH}

This study took place in all regions of Indonesia. The study began October 2018 to April 2019. The approach used in this study was a quantitative approach with online survey. Respondents in this study were all millennials Muslim consumers (19-38 years) who have purchase intention of the products at the food outlets and fast food restaurant in Indonesia. The technique of the sample collection is accidental sampling technique. The total numbers of samples were 385 respondents. Data processing technique used in this research was SEM (Structural Equation Modeling) with Lisrel 8.3 software and descriptive analysis with SPSS 22.

Based on the empirical studies conducted, it was assumed that halal awareness, halal certification and halal marketing have an effect to halal purchase intention. The conceptual framework was presented in Figure 1 as follows: 


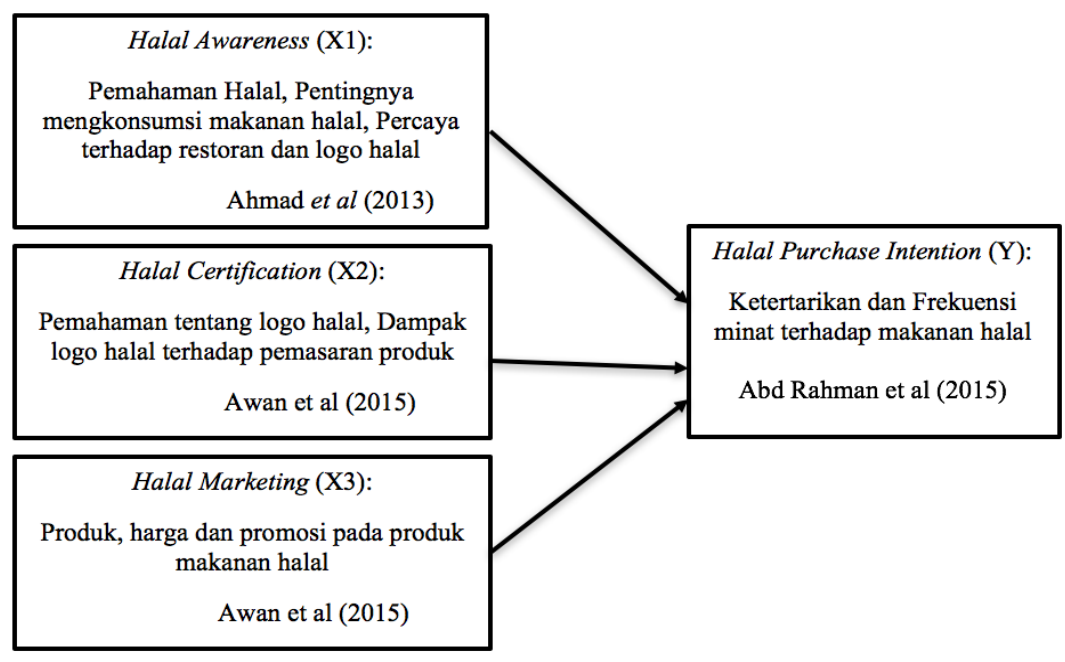

Figure 1 - Conceptual Framework

Based on the conceptual framework above, the proposed research hypotheses are: $\mathrm{H}$ 1: Halal awareness has a positive and significant effect on lawful purchase intention; $\mathrm{H} 2$ : Halal certification has a positive and significant effect on lawful purchase intention; H3: Halal marketing has a positive and significant effect on lawful purchase intention.

\section{RESULTS AND DISCUSSION}

Characteristics of gender identify purchase intention of fast food tends to be done by women than men. Women's high interests to fast food are driven by practical food so that women do not need to buy groceries as well as a waste of time to cook. Millennial Muslims who aged 19-23 years is more dominant in doing purchase intention of fast food. Millennials now like to gather and spend their time at a fast food place, so that the interest aged 19-23 years against fast food is higher. Respondents who have good job are more likely to have interest in buying fast food. Respondents whose income less than Rp.1. 500,000 is a respondent who has interest in buying fast food. Consumer purchasing ability with an income of Rp.1. 500.000 prefers food based on the sale price and taste. Fast food is a solution of food at a bargain price and good taste. Purchase intention fast food tends to be done by people who are not married yet. People who are unmarried have flexible time and tend to have flexible preferences in making purchasing decisions on food. Married consumers pay more intention in selecting food consumption for either individuals or families. Most Muslim respondents millennial lived in the Java island, and the millennial Muslims in Java more dominant consume fast food than in other regions. The information can be seen in the following table 1 .

The table shows the relationship among the variables halal awareness, halal certification, marketing halal and halal purchase intention by demographics for instance gender, age, occupation, income, status and region. It should be noted by fast food marketers that the relationship between demographic variables to be one way to look at the target market segment and millennial Muslims. Men have a higher halal awareness in comparison to women, but not for halal certification, and halal marketing purchase intention. This is because women are more curious about the halal certification than men and interest toward halal purchase intention is also high as the halal marketing.

The age range of 29-33 years have higher halal awareness, but for halal certification age range of 24-28 years and 34-38 years had a curious high level of halal certification, aged 24-28 years have higher halal marketing than that others in reverse for the halal purchase intention aged 29-33 years have a high desire for buying interest against halal food. This happens either because they are influenced by employment and income. There is a 
significant difference in halal awareness, halal certification, halal marketing and halal purchase intention on employment and income.

Table 1 - Average - Average score a variable based on the respondent's profile

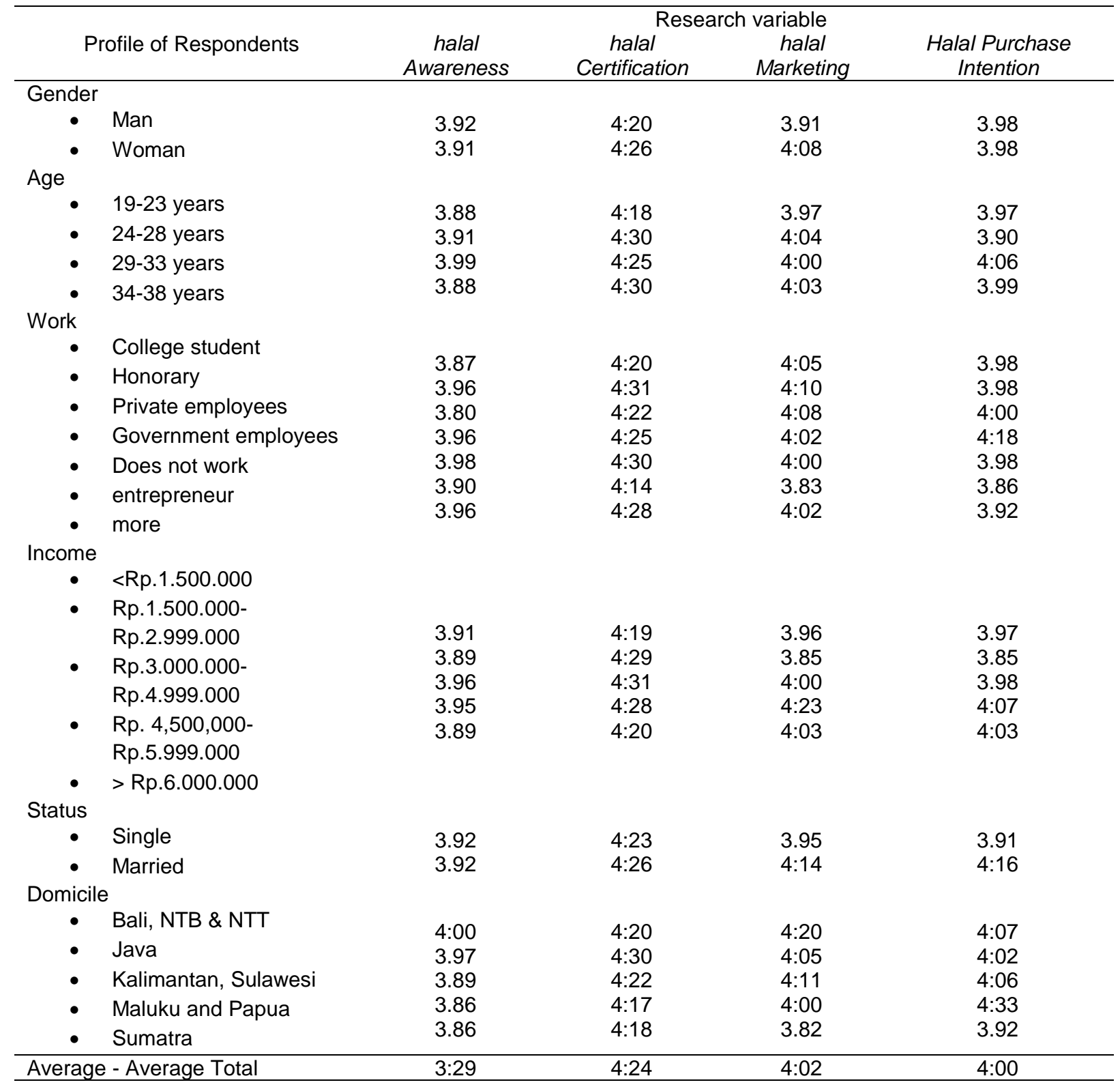

Both unmarried and married respondents have same halal awareness, but not halal certification, and halal marketing purchase intention. There is a difference between respondents who are unmarried and married. This is because the millennial married Muslim consumers pay more attention on deciding of individual consumption needs as well as for long term purchasing intention.

Unmarried millennial Muslim consumers ae more flexible in buying fast food they are influenced by the marketing carried out by fast food restaurants. Region also play important distinction for halal awareness, halal certification, halal marketing and halal purchase intention. Relations domicile and halal certification. While other variables did not show relationship. Omar et al (2008) reveals that halal certification is not a problem issue in Kelantan since most of the population is Muslim consumers so that consumers tend to ignore the halal certification in the consumption of food products.

But it is different if a place where Muslim is minority so they are aware of halal products and halal certification at a fast food restaurant which they will choose is the solution to attract 
purchase intention of Muslim consumers. This condition can be utilized as a marketer to focus on the halal certification and halal marketing on their fast food products.

Compatibility test model can be seen from RMSEA, GFI, AGFI, IFI, NFI, CFI as can be presented in the following Table 2. The overall aspects score of the compliance criteria was in Good Fit category for overall it is claimed eligible.

Table 2 - Results of the overall compatibility test models (overall model fit)

\begin{tabular}{cccc}
\hline Goodness-of-Fit & Cut-off-Value & result & Conclusion \\
\hline RMSEA & $\leq 0: 08$ & 0071 & Good fit \\
GFI & $>0.90$ & 0.97 & Good fit \\
AGFI & $>0.90$ & 0.96 & Good fit \\
IFI & $>0.90$ & 0.98 & Good fit \\
NFI & $>0.90$ & 0.96 & Good fit \\
CFI & $>0.90$ & 0.98 & Good fit \\
\hline
\end{tabular}

Scoring result for testing the goodness of fit showed RMSEA which score was 0071 $0: 08$, it means the model is already good fit. The use of criteria other goodness of fit is GFI, AGFI, IFI, NFI and CFI the score was $>0.90$, which means the models in category as goodness of fit. Since some indicators showed goodness of fit category the hypothesis testing can be conducted. RMSEA score was of $0.07<0.08$ it means the model was accepted and categorized as good fit in RMSEA criterion. GFI score was 0.97 which indicates that the model is a good fit. AGFI score of 0.96 which indicates that the model is a good fit. Scoring result showed that IFI score of 0.98 , NFI score of 0.96 , and the CFI score of 0.98 showed that the model was in good fit.

Compatibility test for measurement model is conducted by applying validity and Realibity test. Compatibility test for measurement model and variance extracted score (VE) and construct reliability (CR) can be seen in Table 3 as follows:

Table 3 - Compatibility measurement model test and variance extracted and construct reliability

\begin{tabular}{|c|c|c|c|c|c|c|c|}
\hline \multirow[b]{2}{*}{ Construct } & \multirow[b]{2}{*}{ Indicator } & \multirow[b]{2}{*}{ Loading factor } & \multirow[b]{2}{*}{ T- count } & \multicolumn{2}{|c|}{ Validity test } & \multicolumn{2}{|c|}{ test Reliability } \\
\hline & & & & $\begin{array}{c}\text { VE } \\
>0.5\end{array}$ & Information & $\begin{aligned} & \text { CR } \\
> & 0.70\end{aligned}$ & Information \\
\hline \multirow{6}{*}{ Halal Awareness } & HA1 & 0.74 & 29.67 & $0: 54$ & Valid & 0.88 & reliable \\
\hline & HA3 & 0.71 & $23: 10$ & & & & \\
\hline & HA4 & 0.77 & 29.50 & & & & \\
\hline & HA5 & 0.91 & 43.76 & & & & \\
\hline & HA6 & 0.64 & 17.95 & & & & \\
\hline & HA7 & 0.61 & 28.00 & & & & \\
\hline \multirow{5}{*}{ Halal Certification } & $\mathrm{HC} 1$ & 0.67 & $16: 37$ & $0: 51$ & Valid & 0.83 & reliable \\
\hline & $\mathrm{HC} 2$ & 0.72 & $23: 56$ & & & & \\
\hline & $\mathrm{HC} 3$ & 0.72 & 14.77 & & & & \\
\hline & $\mathrm{HC} 4$ & 0.86 & 22.72 & & & & \\
\hline & HC5 & $0: 54$ & 14.93 & & & & \\
\hline \multirow{4}{*}{ Halal Marketing } & HM1 & 0.81 & 19.67 & $0: 51$ & Valid & 0.80 & reliable \\
\hline & HM2 & 0.62 & 15.97 & & & & \\
\hline & HM3 & $0: 54$ & 15.99 & & & & \\
\hline & HM4 & 0.84 & 15.84 & & & & \\
\hline \multirow{5}{*}{ Halal Purchase Intention } & $\mathrm{Pl} 1$ & 0.65 & 33.35 & 0.66 & Valid & 0.90 & reliable \\
\hline & $\mathrm{Pl} 2$ & 0.82 & $15: 03$ & & & & \\
\hline & PI3 & 0.88 & $15: 13$ & & & & \\
\hline & PI4 & 0.88 & $15: 44$ & & & & \\
\hline & $\mathrm{PI} 5$ & 0.80 & $15: 02$ & & & & \\
\hline
\end{tabular}

Based on the result as in standardized loading factor and factor $t$-value diagram it can be categorized that all the variables were valid as shown by score standardized loading factor which was more than 0.5 and the value of the $t$-value of 1.96 significant category. Based on the validity and reliability tests revealed that the models were valid and reliable is indicated by the score of VE> 0.5 it means that the model was valid, and CR> 0.7 means that any latent constructs are valid and reliable. Therefore, it can be concluded that the variables 
used in this study had good reliability or able to measure the construction. The results of the measurement model evaluation showed that the overall model fit to the data, this research was valid and reliable.

The next stage should be conducted after the model was analyzed for compliance is to test the compatibility structural model (structural model fit). There are three indicators which do not affect the halal awareness, and two indicators that do not affect halal marketing. This happens because this study using significance test which significance level is 0.05 (95\% confidence level). Then at a rate of $0.05 \mathrm{t}$ value of each structural equation coefficients must be different than 1.96. The score of $t$-values smaller than 1.96 indicates that no significant relationship or cannot explain the latent variables are designated by arrows. From the above results need the elimination.

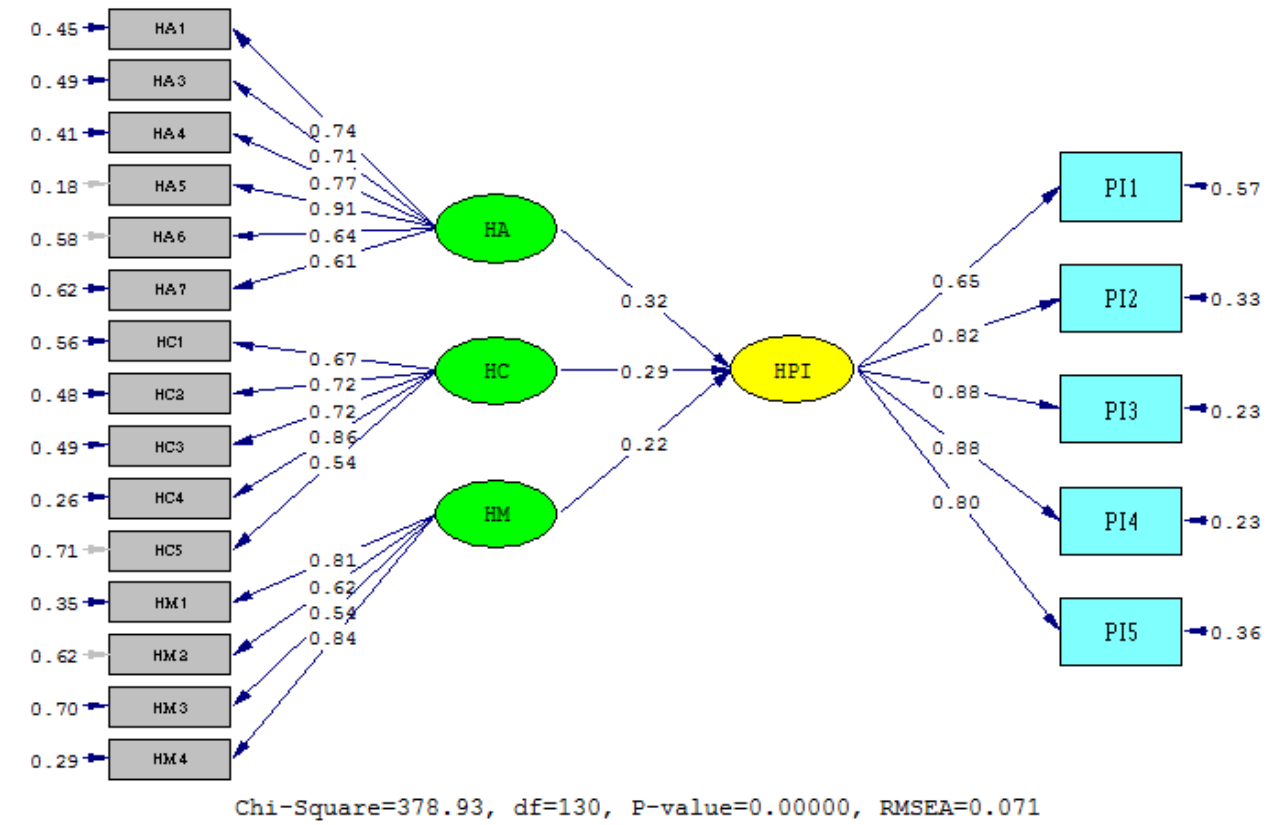

Figure 2 - Image loading factor after elimination

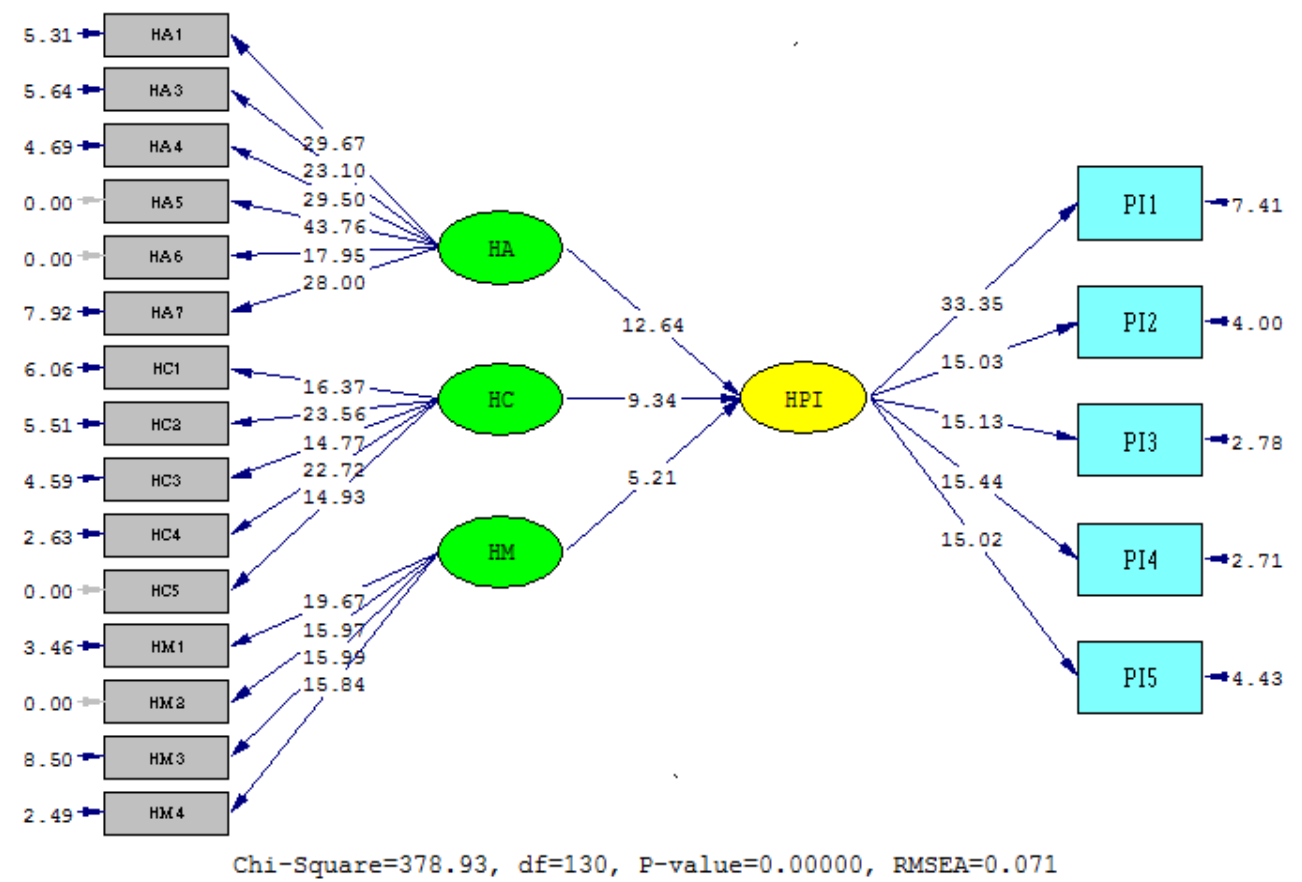

Figure 3 - Picture T-count after elimination 
Table 3 - Estimated result of SEM Model

\begin{tabular}{cccc}
\hline Variables & Standardized loading factor & t-count & Conclusion \\
\hline HA - HPI & $0: 32$ & $12.64^{*}$ & Significant \\
HC - HPI & $0: 29$ & $9: 34^{*}$ & Significant \\
HM - HPI & $0: 22$ & $5: 21^{*}$ & Significant \\
\hline
\end{tabular}

Note: *) value t count> t-table 1.96 means significant influence.

Table 3 explains that all variables have a significant influence on halal purchase intention. It is characterized by positive score obtained in all the variables. This condition is relevant with some other research results which stated that halal awareness, halal certification and halal marketing have a positive influence on purchase intention (Nurhasanah 2018; Awan et al 2015; Shaari 2009). Halal awareness has a positive influence on the halal purchase intention with a positive score $(0.32)$ and $t$-count $=12.64$. Halal certification has a positive influence on the halal purchase intention with a positive score $(0.29)$ and t count $=$ 9.34. Halal marketing has a positive influence on the halal purchase intention with a positive score (0.22) and t count $=5.21$.

Based on this research results, there are three factors that affect the halal purchase intention to fast food that is halal awareness, halal certification and halal marketing. From the above results can be summarized that the most dominant factor is halal awareness, this indicates there are still many millennial Muslim consumers are wary of halal food will be consumed. Millennial Muslim worriless lessens if there is a halal certificate on the product, so that it becomes a second factor that affects halal purchase intention. Hence manufacturers pay more attention to the fast food halal certification, as well as safety for consumers also can be used as a marketing strategy. For halal marketing, millennial Muslim consumers tend to prefer halal products even if the price is high, this is because the millennial Muslims still consider their religion in consuming halal food. Besides, Muslims millennial consumer loyalty is also influenced by familiar brand name but on the results of this research indicate that it is not too dominant. This perhaps caused by millennial Muslims less loyal to a brand. However, a small portion of the millennial Muslim consumers still have to consider the price of halal fast food tend to be expensive. This is because the lack of purchasing power. The producers should determine prices according to the purchasing power of the millennial Muslims in order to compete with other competitors. Manufacturers of fast food needs to pay attention to the relationship between the variables (halal awareness, halal certification, halal marketing, and halal purchase intention) with the demography as a way to select segment and Muslim millennial as marketing market.

\section{CONCLUSION}

The research showed the effect of halal awareness, halal certification and halal marketing toward halal purchase intention. These results revealed that halal awareness, halal certification, halal marketing have a positive influence on halal purchase intention.

Based on the research results, this study only analyzed aspects of halal awareness, halal certification and halal marketing. For the next research it highly is recommended to add variables such as Islamic advertising and brand which also yield an effect on halal purchase intention. The object for further research is expected to be more specific and add the data collection methods such as direct interviews with respondents.

\section{REFERENCES}

1. Agriculture and Agri-Food Canada. 2016. The Foodservice Profile - Indonesia. GOC [Internet]. [Downloaded 2018 Nov 10]. Available at:http://www.agr.gc.ca/eng/industrymarkets-and-trade/international-agri-food-market-intelligence/asia/marketintelligence/foodservice-profile-indonesia/?id=146895041158 
2. Ahmad NAB, Abaidah BTNP, Yahya MHBA. 2013. A study on Muslim halal food awareness among customers in the Klang Valley. In The 4th International Conference on Business and Economic Research (4th ocber 2013) Proceedings (pp. 1073-1087).

3. Alam Y. 2013. Business Ala Fast Food Indonesia. Elex Media Komputindo.

4. Ali H, Purwandi L. 2016. Indonesia 2020: The urban middle-class Millennials. Alvara Research Center.

5. Alserhan, Baker A. 2011. The Principles of Islamic Marketing. Surrey (EN): Gower Publishing Limited.

6. Amelia L. 2018. Several fast food menus from Indonesia. [Internet]. Available at:http://www.abuelaskitchen.com/beberapa-menu-makanan-cepat-saji-dari-indonesia/

7. Ambali AR, AN Bakar. 2014. People's awareness on halal foods and products: potential issues for policy-makers. Procedia-Social and Behavioral Sciences. 121: 3-25.

8. Assael, H. 2004. Consumer Behavior: A Strategic Approach, 6th ed. Boston, MA: Houghton Mifflin Company

9. Cloud HM, 2015. Factors affecting purchase intention halal-evidence from Pakistan's halal food sector. Management Research Review. 38 (6): 640-660.

10. Barton C, Fromm J, Egan C. 2012. The millennial consumer: Debunking stereotypes. The Boston Consulting Group, 16.

11. Farouk O, R. 2017. Fathima Muslim and non-Muslim consumer perceptions of halal at supermarkets in a non-Muslim country: a thesis submitted to Massey University in fulfillment of the requirements for the degree of Masters in Business Studies in Marketing (Doctoral dissertation, Massey University).

12. Jakpat. 2016 Battle of the fast food restaurant-survey report. [Downloaded 2018 Nov 9]. [Internet]. Available at:https://blog.jakpat.net/battle-of-the-fast-food-restaurant-surveyreport/,

13. Janmohamed, S. 2017. Generation M: The young generation Muslims and how they shape the world / Shelina Janmohamed; Yusa translator Tripeni; Ika Yuliana Kurniasih editor. Yogyakarta: Landscape,

14. Mathras D, 2016. The effects of religion on consumer behavior: A conceptual framework and research agenda. Journal of Consumer Psychology, 26 (2), 298-311.

15. Nurhasanah S. (2018). Factors that influence the buying interest in halal processed food products (Case Study in the City / County Bogor). Bogor (ID): Institut Pertanian Bogor.

16. Rania D. 2017. Often practically the same, it is lo 9 difference fast food and junk food. Do unmistakably yes! [Downloaded 2019 Jan 15]. [Internet]. Available at:https://www.hipwee.com/feature/sering-dibilang-sama-ternyata-ini-lo-9-perbedaan-fastfood-dan-junk-food-jangan-salah-lagi-ya/

17. Rashid TH. 2010. Raising the awareness of halal products among Indonesian consumers: Issues and strategies. Indonesian Journal of Agricultural Economics. 1 (01).

18. JA N Shaari Mohd Arifin NS. 2009. Dimension of lawful purchase intention: A preliminary study.

19. Salehudin I, Mukhlish BM. 2012. Halal Marketing: Concepts, Implications and findings in the field. FEUI corpus young economists (pp. 293-305). Jakarta (ID): Issuing Faculty of Economics UI.

20. Schiffman L, LL Kanuk. 2010. Consumer Behavior. Jakarta: INDEX.

21. Shafie S, Othman MN. 2006 Halal certification: an international marketing issues and challenges. In Proceedings at the International IFSAM VIIlth World Congress pp: 28-30.

22. Sharkey JR, 2011. Association between proximity to and coverage of traditional fast-food Restaurants and non-traditional fast-food outlets and fast-food consumption among rural adults. International journal of health geographics. 10 (1): 37.

23. Temporal P. 2011. Islamic branding and marketing: Creating a global Islamic business. John Wiley \& Sons.

24. Tri WN. 2019. Communication among millennial halal lifestyle: enlightening and entertaining.[downloaded 2019 May 10].

25. Wibowo MW, Ahmad FS. 2016. Non-Muslim consumers' acceptance of halal food product models. Procedia Economics and Finance. 37: 276-283. 